\title{
Castleman's Disease: Due to a Rare Intraabdominal Location
}

\author{
Castleman Hastalığı: Nadir Intraabdominal Yerleşim Nedeniyle
}

\author{
Mehmet Cihan Karacaoğlu®, Nursel Yurttutan $\odot$, Betül Kızıldağ $\oplus$, Turgay Kara $\odot$, Sezen Koçarslan $\odot$
}

Cite as: Karacaoğlu MC, Yurttuan N, Kızıldağ B, Kara T, Koçarslan. Castleman's disease: due to a rare intraabdominal location. Forbes J Med. 2021;2(1):49-53.

\begin{abstract}
Castleman disease $(C D)$ is a rare benign disease with unknown etiology. It is also called angiofollicular lymph node hyperplasia, giant lymph node hyperplasia, lymph node hamartoma, benign giant lymphoma. Histologically, it is classified as hyaline vascular and plasma cell variant, but rarely features of two types can coexist. Most of the cases with unisentric disease are hyaline vascular and most of the cases with multicentric disease are in plasma cell histological type. Although it is frequently located in thorax, it can be found throughout the body. Salivary glands, lungs, pancreas, larynx, parotid gland, meninges, and even limb muscles can be affected as extralymphatic spread. Since it is localized in the middle and anterior mediastinum in the thorax, it should be differentiated from mediastinal autoimmune and neoplastic diseases. In this case report, we aimed to present the radiological findings of a CD case with a rare intraabdominal location.
\end{abstract}

Keywords: Castleman Disease, computed tomography, lymph nodes, lymphoma

öz

Castleman hastalığı $(\mathrm{CH})$, etiyolojisi tam olarak bilinmeyen ve nadir görülen benign bir hastalıktır. Anjiyofoliküler lenf nodu hiperplazisi, dev lenf nodu hiperplazisi, lenf nodu hamartomu, benign giant lenfoma olarak da adlandırılır. Histolojik olarak hyalin vasküler ve plazma hücreli varyant olarak sınıflandırılır ancak nadiren iki tipe ait özellikler bir arada bulunabilir. Unisentrik hastalığı olan olguların çoğu hyalin vasküler, multisentrik hastalığı olan olguların çoğu ise plazma hücreli histolojik tipindedir.

Sıklıkla toraksta yerleşim göstermekle beraber tüm vücutta bulunabilir. Tükrük bezleri, akciğer, pankreas, larinks, parotis bezi, meninksler hatta ekstremite kasları ekstralenfatik olarak tutulabilir. Toraksta genellikle orta ve ön mediastende lokalizedir. Mediastinal otoimmün ve neoplastik hastalıklardan ayırt edilmesi gerekir. Burada, nadir bir yerleşim yeri olan intraabdominal yerleşimli $\mathrm{CH}$ olgusunun radyolojik bulgularının sunulması amaçlandı.

Anahtar kelimeler: Casteman Hastalı̆̆ı, bilgisayarlı tomografi, lenf nodları, lenfoma
Received/Geliş: 20.11 .2020

Accepted/Kabul: 24.12.2020

Publication date: 27.04.2021

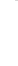

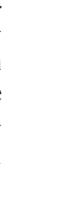

M.C. Karacaoğlu 0000-0002-8510-4866

B. Kızıldağ 0000-0002-0545-0110

T. Kara 0000-0001-8448-9066

Kahramanmaraş Sütçü İmam

Univesity, Department of Radiology

S. Koçarslan 0000-0002-1101-4294

Kahramanmaraș Sütçü İmam

Univesity, Department of Pathology 


\section{INTRODUCTION}

Castleman Disease (CD) was firstly described in 1956 as "localized mediastinal lymph node hyperplasia resembling thymoma". ${ }^{1}$ Later, the definition was expanded and extramediastinal lymph nodes and spleen were included in the definition. $^{2}$

Although more than $70 \%$ of cases are located in the mediastinum or hilus in the thorax, it can rarely localize in the neck, pelvis, pleura, muscle, retroperitoneal region, abdomen and axillary region. ${ }^{2-4}$

It is a rare disease with two histological types defined as hyaline-vascular and plasmocellular CD. Hyaline-vascular type is more common, and it is generally localized in the mediastinum and progresses asymptomatically. Plasmacellular type is less frequent; unlike the hyalen type, fever, weakness, weight loss can be seen. Anemia, leukopenia, hypoalbuminemia, polyclonal hypergamaglobulinemia can be detected. ${ }^{2-5}$

Thymoma, lymphoma, tuberculosis, sarcoidosis and malignant lesions should be considered in the differential diagnosis. ${ }^{3-4}$

Castleman disease should be distinguished from other autoimmune and neoplastic diseases present as a mediastinal mass. Follicular lymphoma, Kaposi's sarcoma, AIDS ("Acquired Immune Deficiency Syndrome") are the diseases that imitate $\mathrm{CD} .^{2}$ Histopathological evaluation is required for definitive diagnosis. Due to difficulties in differential diagnosis, patients are usually diagnosed during thoracotomy.

In this article, we aimed to present the computed tomography (CT) findings and histopathological features of an intraabdominal CD case which was confirmed by total excisional biopsy.

\section{CASE PRESENTATION}

A 25-year-old male patient was referred to our tertiary hospital with symptoms of fever, night sweats and weight loss persisting for a month. No significant disease was found in the patient's history. On physical examination, there was no pathological finding other than a $5 \mathrm{~mm}$ palpable inguinal lymph node. Laboratory test results, including complete blood count, inflammatory markers (ESR, CRP), full metabolic panel, albumin levels were within normal limits. Anti HIV test result was negative.

Abdominal ultrasound (US) revealed a solid hypoechoic mass lesion of $4 \mathrm{~cm}$ in size in the left upper quadrant. For further investigation, contrastenhanced abdomen CT was performed. A wellcircumscribed, round,soft tissue mass with dimensions of $35 \times 32 \times 41 \mathrm{~mm}$ (transverse $\mathrm{x}$ anteroposterior $\mathrm{x}$ craniocaudal diameters) adjacent to the mesenteric vascular structures, and demonstrating significant homogeneous contrast enhancement (mean $\mathrm{HU}=146.3$ ) in the portal venous phase after intravenous injection of non ionic iodinated contrast agent $(2 \mathrm{cc} / \mathrm{kg})$, was detected in the upper left quadrant of the abdomen (Figure 1). There were also heterogeneous densities in the mesenteric adipose tissue around the mass.

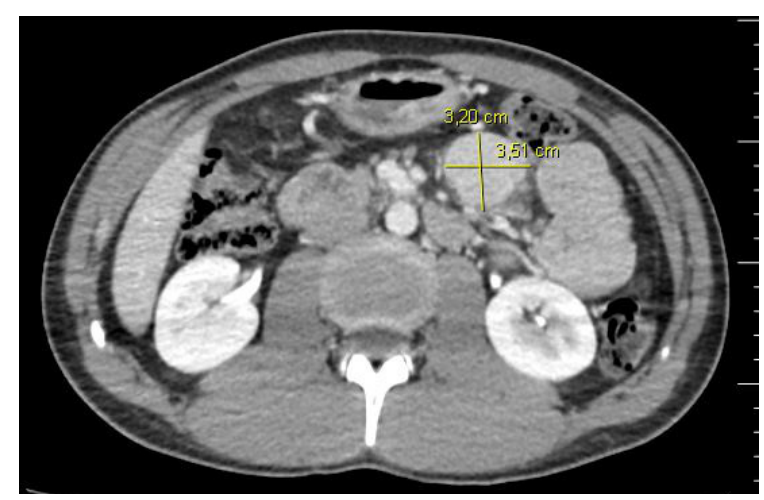

Figure 1. Abdominal Computed Tomography examination is showing, a homogeneous and markedly enhancing mass measured in 35 * $32 \mathrm{~mm}$ within the mesenteric fatty tissue in the upper left quadrant.

In PET-CT, a hypermetabolic mass with an increase in activity at the level of malignancy (SUVmax=6.3) was detected. The patient did not display any evidence of pathology based on the results of physical examination US and analysis of tumor markers for primary testicular cancer.

The patient underwent laparoscopic mass excision performed by the general surgery clinic. A mass lesion with a brown-yellow colored shiny surface surrounded by a $5 \times 5 \times 3 \mathrm{~cm}$ fine capsule was removed. 


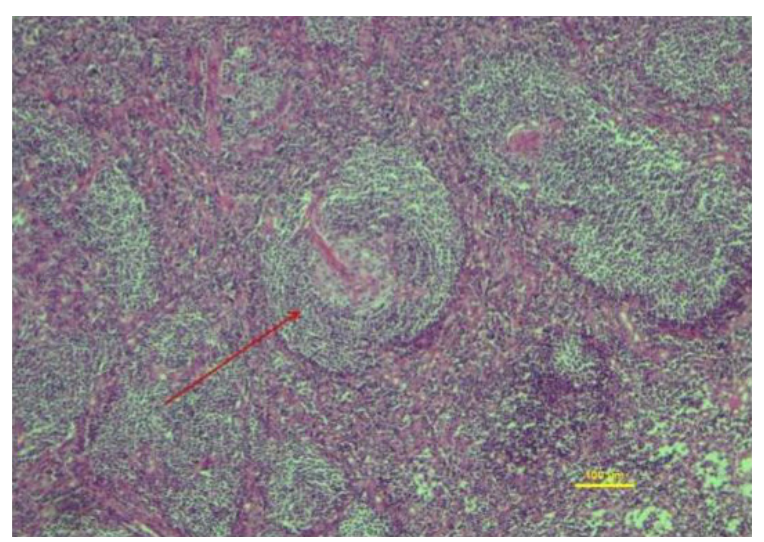

Figure 2. When viewed with a light microscope using 100 magnification with HE stain; the shrinkaged hyalinized germinal centers in the lymph node were radially penetrated by the capillary vein (red arrow) and the lymphoid follicle had the typical "lollipop" appearance. The hyalinized germinal centers are found to be surrounded by a thick mantle zone surrounded by concentric layers of small lymphocytes (target follicle).

In histopathological examination; it was observed that the shrinked hyalinized germinal centers in the lymph node were radially penetrated by the capillary veins and the lymphoid follicle had the typical "lollipop" appearance. The hyalinized germinal centers were found to be surrounded by a thick mantle zone surrounded by concentric layers of small lymphocytes (target follicle) (Figure 2).

The patient was diagnosed pathologically as "hyaline-vascular CD". Since a single focus was detected in PET-CT examination, the patient was considered as having unicentric $C D$. One month later, the patient was evaluated by abdominal US examination and no mass lesion was detected. Currently, the patient is being followed up by the hematology department.

\section{DISCUSSION}

$\mathrm{CD}$ belongs to an atypical lymphoproliferative disease group. Clinically, it is grouped as localized type that affects one region or systemic type that affects more than one region. Localized form was firstly described by Castleman in 1956 and systemic form by Gaba ${ }^{6}$ in 1978.

The pathogenesis of $C D$ is not fully understood, but the role of IL- 6 in unicentric disease, IL- 6 and HHV-8 in multicentric disease are well defined. Increased production of IL- 6 stimulates the production of acute phase reactants in the liver which induces constitutional symptoms and laboratory abnormalities such as anemia, elevation in inflammatory markers, hypergammaglobulinemia, hypoalbuminemia etc. IL-6 also stimulates B cell proliferation and increases angiogenesis. ${ }^{7}$

Systemic form has the risk of developing malignant diseases such as multiple myeloma, B cell neoplasms, Kaposi's sarcoma. It is usually symptomatic and interleukin 2 increase is blamed for this. No consensus has yet been reached in the treatment of its systemic form. Different treatment combinations are being applied. The most commonly used treatment is the combination of surgical excision, corticosteroid and chemotherapy. In recent years, interferon alpha, retinoic acid and anti interleukin 6 antibodies have been recommended for treatment. However, the prognosis of the multicentric form is poor.

The localized form is $51 \%$ asymptomatic. It is detected on routine radiographs. The size of the mass can vary from $1 \mathrm{~cm}$ to $12 \mathrm{~cm}$ ya da vary between 1-12 $\mathrm{cm}$. Depending on the location and size of the mass, pressure findings such as pain and shortness of breath can be seen. It is less likely to turn into malignancy. Permanent cure is provided with surgical treatment which achieves 5 -year survival in all $(100 \%)$ cases. $^{1-2}$

Two histopathological types as hyaline-vascular and plasma- cellular, variants have been described by Keller et al. ${ }^{8}$ Plasma cellular type is less common. It is usually multicentric. Hyalinevascular type is encountered 10 times more frequently than plasma-cellular type. It is usually localized, and most common in the mediastinum (52\%). It may also be located in the neck, axilla, retroperitoneal region, mesentery and pelvis. ${ }^{?}$

Although our case had the most common hyalinevascular type histopathologically, it was seen in rarely encountered intraabdominal location.

The diagnosis is made by excisional lymph node biopsy. Core biopsy is preferred for fine needle aspiration for deep and difficult to reach lymph nodes because fine needle aspiration has a low sensitivity. ${ }^{7}$ 
Castleman disease is a diagnosis of exclusion. Histological features can be confused with both benign and neoplastic conditions. Careful histological examination, immunohistochemical methods, flow cytometry, molecular genetic testing, clinical, laboratory and radiological findings provide a distinction. Conditions that may show histopathological characteristics similar to $C D$ are angioimmunoblastic $\mathrm{T}$ cell lymphoma, early interfollicular Hodgkin lymphoma, early-stage follicular lymphoma, early-stage mantle cell lymphoma, Waldenström macroglobulinemia, rheumatoid arthritis lymphadenitis, syphilitic lymphadenitis, HIV-related common lymphadenopathy and IgG4 associated disease. $^{\text {? }}$

After the final diagnosis of $C D$ is established and the histological subtype is defined, clinical staging should be made to determine the treatment decision and prognosis. The objectives of staging and pretreatment evaluation are to decide whether the patient has unicentric or multicentric disease, to identify systemic inflammatory findings and to reveal the presence of HIV. ${ }^{7}$

Initial laboratory tests include complete blood count, analyses of inflammatory markers (ESR, CRP), complete metabolic panel and albumin. HIV testing should be requested from all patients. Plasma HHV-8 DNA level should also be checked because it correlates with symptoms and supports the diagnosis of multicentric $C D$. It is also a helpful biomarker in monitoring disease activity and treatment response. Although cytokine levels, especially IL-6 and IL-10, are used as disease activity markers in clinical studies, routine measurements are not recommended. If POEMS (polyneuropathy, organomegaly, endocrinopathy, myeloma protein, and skin changes) syndrome is suspected, immunofixation should be requested with serum protein electrophoresis. Careful skin examination should be performed in patients with HIV-associated multicentric CD for Kaposi's sarcoma, which has not been previously diagnosed. ${ }^{7}$

Chest, abdomen, and pelvis CT should be performed to assess the presence of adenopathy and splenomegaly. With these imaging methods, the resectability status in unicentric $C D$ is revealed. Although the lymph nodes retain fluorodeoxyglucose in multicentric $C D$, the diagnostic role of routine PET-CT is not clear. ${ }^{7}$

$\mathrm{CD}$ is generally seen in CT as a well-circumscribed soft tissue mass. Calcification is not frequent. Small masses can be homogeneous, large masses may be more heterogeneous. The hyaline-vascular type is more contrast-enhaced due to its hypervascular nature. With angiography, bronchial, internal mammarial or intercostal arteries feeding the vascular tumor can be displayed. ${ }^{10}$

Conventional T1 and T2-weighted magnetic resonance (MRI) and dynamic MR images do not provide different information from CT. ${ }^{11}$ In imaging with MRI, the lymph nodes of the CD appear as solid masses. The mass displays medium or high signal intensity in the $\mathrm{T} 1$-weighted series compared to the muscles, and mild hyperintense in the T2-weighted series. The presence of intralesional flow in $\mathrm{T} 1$ and T2-weighted images reflects the vascularity of the mass.

Abnormal uptake can be detected in lymph nodes with PET- CT while they retain their normal size. The method is also useful in detecting multifocal foci. Thus, it can be used in the exact staging of the disease and in directing the treatment.

Several studies have been published showing that intraoperative bleeding is minimized by preoperative arterial embolization in vascular type tumors. ${ }^{12}$

Surgical treatment of hyaline- vascular type is the first option. The 5 -year life span is $100 \%$ with surgical excision. In the unifocal type of the hyaline- vascular type, there is little possibility of developing malignancy. In cases inappropriate for surgical treatment, radiotherapy or treatment with a steroid accompanied radiotherapy is recommended. ${ }^{4}$

\section{CONCLUSION}

Castleman disease is a rare, lymphoproliferative disease often localized in the mediastinum or 
hilus. Less often it can be seen in other regions. Regardless of its localization, CD should be considered in the differential diagnosis in the presence of a hypervascular mass.

\section{Conflict of Interest: None. \\ Funding: None. \\ Informed Consent: None.}

\section{REFERENCES}

1. Yeh CM, Chou CM, Wong LC. Castleman's disease mimicking intrapulmonary malignancy. Ann Thorac Surg. 2007 Aug;84(2):e6-7. doi: 10.1016/j.athoracsur.2007.04.042. PMID: 17643599.

2. Jemi Olak. Benign lymph node disease involving the mediastinum. In: General thoracic surgery. 5.th. ed. Philadelphia: Lippincott Williams and Wilkins; 2000 p. 2254-2255.

3. Dural K, Ulaşan N, Yıldırım E, Ulan S. Castleman hastalıklı bir olgu. Özyardımcı N, editör. 25. yıl Akciğer günleri kongre kitabı. Bursa / Türkiye; 6 -10 Mayıs 2000:267-71.

4. Bowne WB, Lewis JJ, Filippa DA, et al. The management of unicentric and multicentric Castleman's disease: a report of 16 cases and a review of the literature. Cancer. 1999;85(3):706-717 doi:10.1002/ (sici) 1097-0142(19990201)85:3<706: :aid cncr21>3.0.co;2-7

5. Blankenship ME, Rowlett J, Timby JW, Roth RS, Jones RE. Giant lymph node hyperplasia (Castleman's disease) presenting with chylous pleural effusion. Chest. 1997 Oct;112(4):1132-3. doi: 10.1378/ chest.112.4.1132. PMID: 9377933.
6. Gaba AR, Stein RS, Sweet DL, Variakojis D. Multicentric giant lymph node hyperplasia. Am J Clin Pathol. 1978 Jan;69(1):86-90. doi: 10.1093/ ajcp/69.1.86. PMID: 619617.

7. Soumerai JD, Sohani AR, Abramson JS. Diagnosis and management of Castleman disease. Cancer Control. 2014 Oct;21(4):266-78. doi: 10.1177/107327481402100403. PMID: 25310208.

8. Keller AR, Hochholzer L, Castleman B. Hyalinevascular and plasma-cell types of giant lymph node hyperplasia of the mediastinum and other locations. Cancer. 1972;29(3):670-683. doi: 10.1002/1097-0142(197203)29:3<670::aidcncr2820290321>3.0.co;2-\#

9. Somdas MA, Ketenci I, Bicer S, Senturk M, Guney E. Castleman's disease as an unusual neck mass: case report. Ann Otol Rhinol Laryngol. 2004 Jun;113(6):459-61. doi: 10.1177/000348940411300608. PMID: 15224829.

10. Madan R, Chen JH, Trotman-Dickenson B, Jacobson F, Hunsaker A. The spectrum of Castleman's disease: mimics, radiologic pathologic correlation and role of imaging in patient management. Eur J Radiol. 2012 Jan;81(1):123-31. doi: 10.1016/j. ejrad.2010.06.018. Epub 2010 Jul 18. PMID: 20643523.

11. Pekçevik Y, Gürel D, Şanlı A, Kargı A, Osma E, Yılmaz E. Mediastinal Castleman Disease: Preoperative Radiological Evaluation of Vascularity. Tur Toraks Der. 2010;11: 127-130. doi:10.5152/ttd.2010.19

12. Yurttutan N, Çiftçi T, Sağlam A, et al. Pelvic Positioned Castleman Disease; Radiological and Pathological Findings: Case Report. Medical Journal of Kahramanmaraş Sütçü İmam University. 2011 ;(8)1: 44-48 